\title{
Total Market Orientation, Customer Value, And Market Performance From A Dual Perspective
}

Laurent Tournois, DBA, Grenoble Ecole de Management, France

\begin{abstract}
Most approaches to a market orientation focus on generating superior value for customers. Doing so determines the strength of the firm's competitive advantage and thus its level of performance. This article considers this causal chain from a dual perspective, that is, that of companies and their customers. Data collected from 55 companies, involving 146 managers and 425 consumers of branded products that these companies sell, indicate that market orientation correlates with customer value (weak link but statistically significant) but not with a subjective measure of market performance, that is, with customer satisfaction. Moreover, perceived value affects market performance, a finding that corroborates the theory that a business that creates value that a consumer perceives as superior will enjoy improved market performance.
\end{abstract}

Keywords: Market Orientation; Customer Value; Market Performance; Customer Satisfaction; Dual Perspective

\section{INTRODUCTION}

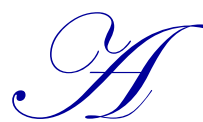

lternating phases of growth and contraction in consumer product markets over the past 20 years has stimulated thinking about the ability of marketing organization models to compete effectively in a changing market place (see BCG, 2012). Marketing researchers responded to these concerns by suggesting that companies must be culturally market oriented to create an internal environment that encourages firm behaviors that create superior value for customers, both locally and internationally, if the companies hope to achieve stronger performance than their competitors. Moreover, this assumption, a founding principle of market orientation theory, appears to be losing ground in the academic world. In recent years, interest in market orientation as a research topic has weakened considerably, to such a level that some researchers even herald its end (Rossiter, 2012) as it seems to suffer from conceptual and measurement issues (Uncles, 2011). Nonetheless, can we definitely state that market orientation has no role in a company's pursuit to create superior customer value and performance than its competitors?

First, the causal sequence, market orientation $\rightarrow$ perceived value $\rightarrow$ performance, raises questions about the role of customers and their evaluations of the effectiveness of market orientation. Issues of judgment and perception have been raised as important considerations in market orientation research (Noble, Sinha, \& Kumar, 2002). 20 years ago, adopting a customer-centric view of market orientation, Deshpandé, Farley, and Webster (1993) used the term "customer focus" synonymously with "market orientation," to stress that assessments of the level of orientation of a company should come from customers rather than the company. Indeed, customers evaluate a firm's market orientation solely on the basis of "how the firm listens to their needs" (Grisaffe \& Kumar, 1998) because they have little or no knowledge about its internal processes. Thus, customers' perceptions, opposed to those of vendors or managers, about the extent to which a company is customer oriented are the true critical measures of business performance. Moreover, using customers' evaluations avoids common method biases related to manager's selfevaluations of both market orientation and business performance of their own business unit(s) (Rong \& Wilkinson, 2011). 
Second, to date, one of the most recent conceptualization of market orientation combining proactive and responsive/reactive behaviors (Narver, Slater, \& McLachlan, 2000, 2004) provides only a partial contribution by adopting a unique (supply-side) perspective, that of the company. In addition to recent works on his topic (e.g. Zhou, Brown, \& Dev, 2009), the adoption of a dual approach, a relatively unexplored research area, might better reveal the significance of customer value in the implementation of market orientation especially in subjective evaluations. Therefore, investigating market orientation and its consequences from the perspectives of both the firm and its customers, contributes to empirically validate the fundamental assumption pertaining to market orientation.

This study investigates the links between market orientation, customer value, and satisfaction considered as a subjective indicator of the company's market performance. This study also posits that customer value mediates the relationship between market orientation and market performance. Indeed, it seems unlikely that the widely considered relationship between market orientation and performance is direct (McNaughton, Osborne, and Imrie, 2002). Despite the growing number of studies on mediating effects (e.g. Camarero \& Garrido, 2008; Carbonell \& Rodríguez Escudero, 2010; Voola, Casimir, Carlson, \& Agnihotri, 2012), literature on market orientation remains largely theoretical with regard to identifying customer value as a mediator between market orientation and overall performance.

This research examines the relationships between market oriented companies (corporate brands) and their customers' perceptions of their branded products. Research that jointly regards brand and market orientation is still in its infancy because the two are considered to be distinct strategic options (Urde, Baumgarth, \& Merrilees, 2011). In a dual perspective, this study extends existing knowledge by considering brand orientation, the inside-out approach, and market orientation, the outside-in approach, as non-mutually exclusive.

\section{CONCEPTUAL BACKGROUND AND HYPOTHESES DEVELOPMENT}

\section{A dual manager-customer perspective}

The evaluation of organizational phenomena, such as market orientation, raises the question of whose perspective to adopt, that is, of employees, customers, suppliers, etc. Rather than considering them as antagonists, the multisource instrument called " $360^{\circ}$ feedback" (Tornow, 1993) has been developed (see also Bracken, Timmreck, Fleenor, \& Summers, 2001). This view posits that the evaluation of a group of organizational actors (managers, executives, employees, etc.) that self-assess themselves, is compared to the evaluations made by another group of key stakeholders (customers, suppliers, shareholders, etc.).

In the marketing literature, the study from Netemeyer and Maxham (2007) involving a triad of supervisors, employees, and customers, strongly encourages use of 360-degree feedbacks. Within research on the evaluation of the effectiveness of market orientation, a dual or dyadic perspective implicitly recognizes the existence of differences (perceptions) between self-reports of company employees and the evaluations of its customers. Several studies account for the viewpoints of the company and its customers together, to assess the company's market orientation. Their results highlight that market orientation's ability to generate superior performance is based on integrating the customers' perceptions into the process (e.g., Langerak, 2001; Siguaw, Simpson, \& Baker, 1998; Voss \& Voss, 2000). These approaches revolve around the principle of "interactivity" that exists in inter-firm relationships. They assume that the nature and characteristics of a company's offer(s) are a direct function of its level of market orientation. Their main contribution lies in their ability to account for customer perceptions in evaluating the effectiveness of the firm's market orientation.

Thus, building on the findings provided by Webb, Webster, and Krepapa (2000) and recently by Terawatanavong, Whitwell, Widing, and O'Cass, (2011), this study assumes that customers, especially those in long-term relationships, are qualified to express their opinions and shape their evaluations, both cognitive (perceived value) and emotional (satisfaction), of an offer, which reflects the level of market orientation of that company. 


\section{Market orientation and customer value}

Research on market orientation reveals three dominant conceptualizations, all of which suggest ways to create and deliver superior value to customers (Langerak, 2001), introduced by Kohli and Jaworski (1990), Narver and Slater (1990), and Deshpande et al. (1993). Then Narver, Slater, and MacLachlan (2004) combined these three conceptualizations through a synthesis of previous approaches that also aimed to extend their boundaries. They argue that market orientation exists in two essential and complementary forms: "reactive" (or "driven by the customer" in Slater and Narver's [1998] terms and "constrained by the customer" in Day's [1999] terminology) and "proactive". The latter refers to a company trying to uncover and satisfy the customer's latent needs. Yet, in a previous work, Narver et al. (2000) showed that including a proactive market orientation significantly increases the explanatory power of the reactive market orientation on company's performance, and introduced the concept of "total market orientation". The underlying rationale is that of a positive interaction, the two market orientations complement each other. In a consumer goods context, it is likely that firms engage in both simultaneously, and transition from one form to another is part of a dialectic influenced by the relationship between the company and its environment, i.e., consumers [demand] competitors [their behavior on the market] and market conditions [growth, stability, decline] in a broad sense (e.g. Kohli \& Jaworski, 1990). To date, there is no study examining both proactive and reactive behaviors as dimensions of the same construct. Thus, this research advances knowledge regarding conceptual developments about market orientation. Hence,

H0: Total market orientation comprises a proactive dimension and a reactive dimension.

H0a: Proactive market orientation and reactive market orientation are related but distinct constructs.

The majority of the research tends to take a "component-wise approach" (see Matear, Osborne, Garrett, and Gray, 2002) to the relationship between market orientation and market performance. This is contrary to Jaworski and Kohli's (1996) contention that market orientation is broader than any of its underlying dimensions. In this study, market orientation is treated as a construct that incorporates proactive and responsive/reactive behaviors. Therefore, based on the findings of Narver et al. (2000), this study assumes that for any business, the best basis for a sustainable competitive advantage and better performance is to be totally market oriented, combining a reactive market orientation with a proactive one.

These authors initiated a research trend that agrees these two forms of market orientation if statistically related, still separate concepts. Their respective effects on variables related to product innovation activity and performance have been explored (e.g. Bodlaj, 2010; Jiménez-Zarco, Torrent-Sellens, \& Martínez-Ruiz, 2012; Voola \& O'Cass, 2010; Zhang \& Duan, 2010) but their effect on customer value remains understudied. Recently, Blocker, Flint, Myers and Slater (2011) have provided substantial additional insights by showing that the interaction of proactive and responsive customer orientation creates superior value in a business-to-business (B2B) setting. By "giving voice to customers", their argument lies in the development of a customer-defined proactive customer orientation that combines with a responsive customer orientation.

However, this stream of research on market orientation shows excessive dependence on the context of B2B relationships and therefore is limited in its applicability to business-to-consumer (B2C) settings. In the B2C realm, the assumption of a joint assessment of market orientation by the company and the customer is not realistic, because end customers lack sufficient information. In line with this, the assessment of the company's market orientation reflects the perceptions of its managers, while the value perceived by the customer has to be defined by customers (Weinstein \& Pohlman, 1998).

Over time, the concept of value has gradually been enriched by inputs from different research streams from the marketing and strategic management fields. In these works, perceived value becomes the key explanatory variable (related to consumer behavior) of company performance. In strategic management terms, customer perceived value is a strategic opportunity for differentiation. It plays a pivotal role in determining the competitiveness of a company, such that its relative dimension is key. As Porter (1985-1999, p. 54) notes, "In terms of competition, value is the sum of what customers are willing to pay a firm that supplies/offers them." Marketing literature instead addresses how customers perceive value. In this realm, many authors recognize the difficulties of 
defining value (see Piercy \& Morgan, 1997). This study retains from the widely accepted affirmation that qualityprice trade-offs are part of the process by which customers estimate the value of an offer (Bolton \& Drew, 1992). Although perceived value may originate from sources that include a price-quality trade-off, and go beyond them (Grisaffe \& Kumar, 1998), this article does not simply adopt this conceptualization but rather use it to facilitate the operationalization of this variable in the empirical examination of the hypotheses.

The value perceived by the customer thus is a dynamic concept that emerges and evolves over time (Flint \& Woodruff, 2001), through continuing series of transactions and relationships. Thus, companies cannot rely on past sources of value to estimate future sources (Audia, Locke, \& Smith, 2000; Hamel \& Prahalad, 1994). These characteristics of perceived value emphasize a fundamental requirement for companies: to identify customer needs, particularly latent or unarticulated ones, to support more precise aspects of an offer that can generate stronger perception of its value compared with competitive offerings. This anticipatory or proactive approach is one of the pillars of the market orientation definition given by Narver et al. (2000, 2004). In the meantime, an organization first address its target customers' expressed needs before attempting to satisfy their latent needs (Narver et al. 2000), therefore adopting a reactive/responsive behavior. If we consider the search for long term relationships by brands in consumer goods markets, we further assume that companies will articulate both types of market orientations to attain a dominant competitive position and in to maintain this position through continuous creation of superior value for its customers. Therefore,

H1: Market orientation positively influences customer value.

\section{The mediating role of customer value between market orientation and market performance}

While the majority of the findings reveal that market orientation positively influences performance, the influence of market orientation on market performance has yet to be confirmed. Reinartz, Krafft, \& Hoyer (2004) conceptualize market performance as a mediator (Day \& Wensley, 1988; Varadarajan \& Jayachandran, 1999), between the company's marketing activities and its economic performance. In turn, market performance connects a company's managerial actions to variables such as customer satisfaction (Fornell \& Johnson, 1993) and earnings growth (Chakravarthy, 1986). Thus, satisfaction represents a key subjective measure of market performance, considering its ability to provide information complementary to traditional accounting and financial measures (Ittner \& Larcker, 1998).

Marketing literature offers at least two conceptualizations of satisfaction: a transaction-specific one and a cumulative one (Boulding, Lee, \& Staelin, 1993). Cumulative (or aggregated) customer satisfaction is an overall assessment, based on the overall buying and consumption experience of a product or service over time (Fornell, 1992; Johnson \& Fornell, 1991). Although satisfaction related to a particular transaction can provide information related to a specific diagnosis about a product or particular service, cumulative satisfaction is a more fundamental indicator of a business's past, present, and future performance (Anderson, Fornell, \& Lehmann, 1994). Accordingly, this study considers cumulative satisfaction a central subjective evaluation of the market performance of the company. This position is based not only on its synthetic properties but also on the company's ability to generate wealth in the future.

Research on customer satisfaction illustrates this role, but few studies address the relations between satisfaction and its antecedents, including the firm's market orientation and customer perceived value. In regard to the latter, Woodruff, Schumann, and Gardial (1993, p.33) stress that "in the decade ahead, organizations will rise or fall based on their ability to deliver value that satisfies targeted customers", calling for additional research on this topic. In the market orientation literature, studies give empirical support for indirect contribution of market orientation on market performance, whether the influence transits through competitive advantage (Zhou et al., 2009) or customer value (Blocker et al., 2011). The latter shows that customer value fully mediates the effects of proactive and responsive customer orientations on satisfaction. While the mediating role of customer value in the relationship between market orientation and market performance is not well-documented, this study adds to the literature by suggesting that in consumer goods markets, market orientation enhances company market performance (i.e. customer satisfaction) indirectly, through customer value: 
H2: Customer value mediates the relationship between market orientation and market performance that is customer satisfaction.

Several authors suggest that customer value strongly affects customer satisfaction (Gale, 1994) and that customer satisfaction is a customer's reaction to value perceptions (Woodruff, 1997). Accordingly,

H3: Customer value positively influences market performance that is customer satisfaction.

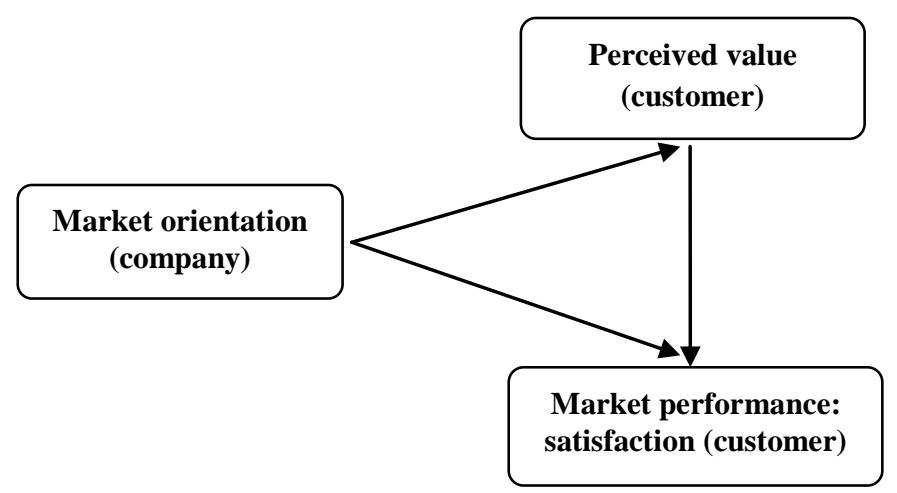

Figure 1 - Conceptual model. The model is seen from a dual perspective.

\section{RESEARCH DESIGN}

This study focuses on multisource assessments of different concepts, including market orientation by the company and perceived value and market performance by the customer, rather than performing cross evaluations of the same concept. Research on market orientation has shown that employees' self-reported customer orientation is misleading, such that data from customers are required (Deshpandé et al., 1993), along with data from the company. Combining these requirements with the need for reliable measurement instruments from both the supply and demand sides, Deshpandé and Webster (1989) note the demand for a complex, expensive research design. Therefore, we limit our study to a specific time period, rather than performing longitudinal data collections from multiple sources. We take into account the different aggregation levels related to the studied variables, such as market orientation and customer-related variables, including perceived value and satisfaction. Thus, the unit of analysis is the triad of customer-product-brand/company.

\section{Sample}

To test the hypotheses, a dual data collection is performed, with a manager questionnaire and a customer questionnaire.

\section{Manager questionnaire}

To develop the manager questionnaire, this research follows the procedure recommended by Narver, Slater, and MacLachlan $(2000,2004)$ and uses the operationalization of the market orientation variable from the conceptual model. The original scale (Narver et al. 2000, 2004) consisted of 15 items, subjected to double translation and translations of certain words and certain sentence formulations were re-corrected. We use a six-point Likert scale, which forced some degree of non-neutrality. Furthermore, the questionnaire is pre-tested before being administered to the entire sample. The pretest validates that respondents understand the various questions and that the terms and modalities of the proposed answers are relevant. Items are provided in the Appendix.

Although not a random sample, the respondents for this study represent a broad spectrum of consumer goods industries such as cosmetics, food, personal computers, automotive, etc. The contact data comes from the alumni directories of several business schools belonging to the Paris Chamber of Commerce. Thus we administered 
the manager questionnaire by telephone (after an email contact), email, or fax, depending on which the contact person preferred. We collected 146 usable manager questionnaires.

To ensure high quality information, this research uses key informants and follows the recommendations of Phillips (1981) to increase the number of key informants within each company. The combination of these two methods grants access to a greater volume of information, in total and for each company. In all cases, the appropriate hierarchical level is middle management (only executives), and the functions represented works in close collaboration with marketing departments, such as advertising/sales functions, customer service, and R\&D, as well as more strategic or transversal functions (Narver \& Slater, 1990; Narver et al., 2000, 2004). In this regard, 81.5\% of our manager sample serves a marketing function.

The average of respondents per company is 2.6 which might create a risk of divergent responses to same items. At the same time, it should not be surprising that some responses differ within the same company, because market orientation can be perceived in various ways. Respondents answer each item on the basis of their own perspective, which reflects their job/position, as well as their previous work experience. Thus, the data collected from managers was carefully reviewed and should predict that respondents with marketing-oriented functions have relatively convergent responses. This prediction is largely confirmed by the analysis of informants' answers within the same firm. Out of 146 informants, $53.4 \%$ are men, and $46.6 \%$ are women. Seniority ranges from 0.3 to 25 years, with a mode of distribution of 3 years. The median age of the managers is 31 years.

Although the managers' data collection process included systematic recall of respondents in case of nonresponse on one or more items, the sample produced three incomplete questionnaires. We considered the answers given by other managers from the same companies on the missing items and discovered that the missing values were randomly distributed. Thus, they likely do not indicate a refusal to answer, as confirmed by the MCAR test of Little that is significant $\left(\chi^{2}=11,92\right.$, df: 16 , sig: .75). To maintain the representativeness of respondents by company in our sample, we keep the three questionnaires and replace the missing values using the "Missing Value Analysis" module of SPSS software.

\section{Customer questionnaire}

The customer questionnaire derives from the operationalization of perceived value and satisfaction variables, in line with the American Customer Satisfaction Index (ACSI) model (Fornell et al., 1996). The items and modalities subjected to double translation. Then the translations of certain words and certain sentence formulations were re-corrected. To the best extent possible, this study complies with the "spirit" of the original scales. The questionnaire is pretested before being administered to the entire sample. After the pretest, we decide to adopt a sixpoint Likert scale (versus a ten-point scale used in the ACSI), because the respondents do not perceive the usefulness of certain modalities (i.e., extreme values such as 1 and $8-10$ ), which reduces their visibility and readability. In addition, we want to be consistent with the manager questionnaire, which also uses a six-point scale.

To qualify a consumer as a buyer of the sample companies' products, the ACSI methodology is used, which considers a respondent qualified if he or she has purchased products within a given period of time (see ACSI Methodology Report, 2001). Thus, purchasing cycles are defined by product type and in relation to the industries. The identification of consumer issues is tailored to each sector in the study. This research assumes that customers are fairly well informed and make comparisons between competing offers at different levels. In this regard, this study adopts Holbrook's (1996) and Holbrook and Corfman's (1985) usage of the terms "relative preference" to define value, such that value is always evaluated with respect to another object. Therefore, customers have relative, voluntarily available information that they use to form value judgments. However, the measurement instruments do not include comparisons or benchmarks with competitive offerings. Finally, the customers interviewed spontaneously noted that they were multi-company product buyers.

The sample is a convenience one. We choose to vary the respondents with respect to certain characteristics (gender, age, socio-professional category) and to distribute the administration by geographic area (intra- and extramural) and according to different product categories by business (e.g., respondents included customers of shampoos, conditioners, and styling products from the L'Oréal brand). The customer questionnaire was administered 
face-to-face and via email. Again, we choose to keep questionnaires in which some items are not completed. Missing values are replaced using the same method that was applied for the managers' questionnaire.

Of the 425 respondents, $48.2 \%$ are men, and $51.8 \%$ are women. Their average age is 33.4 years, but $61.2 \%$ of respondents are younger than 33 years. The distribution of questionnaires according to socio-professional categories shows that the sample is not overrepresented by students ( $41.6 \%$ of the total); instead, it covers a wide range of socio-professional categories, which makes it more representative. More than two-thirds of the sample have a master's degree or higher.

\section{Measures}

To measure market orientation, this research uses the scale developed by Narver et al. (2000), which integrates two dimensions - responsive (MORTN) and proactive (MOPRO) - in a unidimensional scale. The overall market orientation (MOTOTAL) scale thus consists of 15 items (see Appendix). This MOTOTAL scale, to the best of our knowledge has never been tested outside of United States, which raises questions about scale generalizability. Deshpandé and Farley (1998) have shown that measurement problems related to the concept of market orientation should be controlled not only at the conceptual level but also in international research environments and across industries. Because the scale developed by Narver et al. (2000) was developed in part from Deshpandé and Farley's (1998) scale, it is predictable that it can span geographical and industry contexts and is thus suitable for this research.

To measure customer value, this study uses the scale from the ACSI model (Fornell et al., 1996), operationalized with two items: quality relative to price and price relative to quality. This measure is not only based on the main antecedents of perceived value identified in the literature but also focuses on items that are actionable and under the control of the company (see Rust, Zeithaml, \& Lemon, 2000 ).

Customer satisfaction is measured with the relevant scale from the ACSI model as well (Fornell et al., 1996). Cumulative or overall satisfaction is operationalized using three items: (1) an overall score of satisfaction, (2) the degree to which performance is below or above expectations, and (3) a score of performance relative to a customer ideal in terms of product or service in the category (Fornell et al., 1996).

\section{Adequacy of the data for multivariate analysis}

We examine the extreme values and outliers, as well as the normality of the distributions, through a univariate analysis. The identification and elimination of outliers and extreme values takes place after reviewing the box plots for each variable. Thus, we verify that the outliers are not due to mistakes. In observing the pattern of responses in both questionnaires, we do not observe any inconsistencies.

We check the normality of the distributions of the variables of our samples. In the manager data, the results of the Kolmogorov-Smirnov test indicate that none of the variables follow a normal distribution. We choose not to transform the variables, because the skewness and kurtosis scores are acceptable. For the customer data, the Kolmogorov-Smirnov test again shows that none of the variables followed a normal distribution. We do not transform the variables, due to the acceptable skewness and kurtosis scores. These results are not surprising; in management science studies, it is rare for the data to follow a normal distribution, due to the use of discrete measures (Roussel, Durrieu, Campoy \& El Akremy, 2002).

\section{Measure refinement and validity}

Preliminary data analyses refine the measures and assess the construct validity and reliability in the following procedure. First, the managers' and customers' samples are randomly divided into two subsamples. Second, exploratory factor analyses (EFA) are carried out on the first subsample. Third, confirmatory factor analyses (CFA) are conducted on the other subsample. In the case of Total Market Orientation (MOTOTAL scale), CFA includes the overall sample. The data are examined using AMOS (Arbuckle \& Wothke, 1999). 
The MOTOTAL scale reduces to 14 items, because one item ("We help our customers anticipate developments in their markets") is related to B2B relationships and does not apply to the B2C context of this research. Considering the lack of empirical studies on the MOTOTAL scale, the tests of the proactive and reactive dimensions follow a systematic exploratory approach, such that each dimension is tested on the first and second subsamples.

\section{Proactive dimension test}

The results for the proactive dimension, which comprised seven items, highlight that the measurement model does not fit to the data as $\chi^{2} / \mathrm{df}$ (Khi-square / degrees of freedom) is 3.87 ( $\mathrm{p}<.001$ ), GFI (goodness-of-fit index; Jöreskog \& Sörbom, 1989) is 0.84 and RMSEA (root mean square error of approximation) is 0.2. The standardized regression coefficients $(<0.5)$ and standardized residuals $(>2.58)$ for each item suggest deleting three items (items 4, 6, and 7) that do not meet the statistical prerequisites. Subsequent to the deletion, indices show satisfactory fit of the model to the data $\left[\chi^{2} / \mathrm{df}=0.26(\mathrm{p}<.001)\right.$; GFI $=0.99$; RMSEA $\left.=0\right]$. Tests conducted on the second subsample indicate similar results except for item 3 . We retain the previous structure though, because deleting it offers few improvements, whereas retaining it allows maintaining the scale direction. Thus, the proactive dimension consists of four items.

\section{Reactive dimension test}

Regarding the reactive dimension GFI, which comprised 7 items, GFI (0.86) shows a moderate fit of the model to the data. This result is confirmed by the examination of other indices such as $\chi^{2} / \mathrm{df}=2.58(\mathrm{p}<.001)$ and RMSEA $=0.15$. The results of the exploratory factor analysis of the first subsample highlight a standardized regression coefficient of less than 0.5 for item 9. A second analysis shows that item 13 also is problematic. Thus, both are deleted. The third analysis indicates that the modified model provides acceptable fit to the data $\left[\chi^{2} / \mathrm{df}=1.6\right.$ $(\mathrm{p}<.001)$; GFI $=0.95$; RMSEA $=0.09$ ]. Analyses carried out on the second subsample show that item 8 might cause problems. In keeping with extant theory, we decide to remove it from the measurement model. The different indicators show a satisfactory fit of the model to the data $\left[\chi^{2} / \mathrm{df}=0.91(\mathrm{p}<.001)\right.$; GFI $=0.99$; RMSEA $\left.=0\right]$. The reactive dimension ultimately includes four items.

Roussel, et al. (2002) state that a correlation in excess of 0.6 between two dimensions suggests the existence of a second-order concept. We proceed to test the first-order model to examine the correlations between the two dimensions. We then conduct an analysis on the second-order model.

\section{The first-order model}

To test the hypothesis of a second-order construct, we add a covariant relation between the two dimensions, proactive and reactive. The first analysis shows that the regression coefficient for item 3 is 0.34 ; therefore, it is deleted. The results of the second analysis indicate a correlation of 0.63 between the two dimensions and show a satisfactory fit of the model to the data $\left[\chi^{2} / \mathrm{df}=0.86(\mathrm{p}<.001)\right.$; GFI $\left.=0.96 ; \mathrm{RMSEA}=0\right]$. Based on prior literature (Roussel et al., 2002), we assume the existence of this construct.

\section{The second-order model}

This analysis shows similar results. The standardized regression coefficient stands out at 0.97 for the proactive dimension and 0.65 for the reactive dimension. The examination of $\chi^{2} / \mathrm{df}=0.86(\mathrm{p}<.001, \mathrm{GFI}=0.96$, and the RMSEA $=0$, respectively show satisfactory fit of the measurement model to the data. Therefore, the existence of a more abstract concept of total market orientation is confirmed and it comprises a proactive and a reactive dimension. Thus, these results give support to $\mathrm{H} 0$ and $\mathrm{HOa}$.

Next, we check the validity and reliability of each construct (i.e. market orientation, customer value and customer satisfaction). Results indicate satisfactory construct reliability (ranging from .77 to .88) and Cronbach's alpha (ranging from .77 to .83) all coefficients being above Nunnally's (1978) 0.7 criteria. The psychometric properties of the measurement instruments are good as well. All the items load on the expected factors/constructs 
(values of the t parameters are significant), which supports convergent validity (Gerbing and Anderson, 1988). The average variance extracted (AVE) ranges from .48 to .70 revealing acceptable values as Green, Barclay, and Ryans (1995) reports that values above .40 can be accepted because in all other respects they appear strong (i.e. loadings above .5 , reliability .7 or higher, and satisfactory discriminant validity). For the customer perceived value measure ( 2 items), the communalities show satisfactory factor loadings (.85 for the first item and .81 for the second). Overall, regardless of the method used, the results show that our measurement instruments possess adequate (convergent and discriminant) validity and reliability.

\section{RESULTS}

In order to test the model (Fig. 1), we implement the following procedure: Each manager is asked about his or her practices in terms of market orientation at the department level. In parallel, each customer is asked about his or her perception of the value of branded products and level of satisfaction toward the same branded products. For managers working in corporate brand companies, we hypothesize that when assessing their business practices, they evaluate the company behind the brand. We next compile a list of corporate brands evaluated by customers and a list of corporate brand companies to which managers belong. Finally, responses from managers and customers about the same company are then averaged to give one response per company on each assessed variable.

The objective of this article is to determine which explanatory variable, market orientation or customer value, is the best predictor of customer satisfaction. The model therefore must have high explanatory power (strong $\mathrm{R}^{2}$ ) and be parsimonious, such that it includes the smallest possible number of explanatory variables. This condition is fulfilled because we have only two variables. Then, prior to examining relationships, we verify that explanatory variables are independent and uncorrelated, using the interpretation grid suggested by Cohen (1988): The values of tolerance and conditional indices met the requirements (tolerance $=.95$; conditional index $=10.58$ ). Then we check the hypothesis about the independence of residuals by inspecting the Mahalanobis distances; the values that result from the statistical table of residuals (Min. $=.02$, Max. $=7.13$, Mean $=1.96)$ are less than the critical value $(13.82)$ proposed by Tabachnick and Fidell (1996) when there are two independent variables (i.e., market orientation and perceived value). The latter indicates that the hypothesis pertaining to homoscedasticity is not violated.

To test our hypotheses, we use multiple regressions analyses (Cohen and Cohen, 1983) and estimate the following regression equations: Customer satisfaction is regressed on customer value; customer satisfaction is regressed on market orientation; and customer satisfaction is regressed on both customer value and market orientation. The results are summarized in Table 1.

First, the model that includes market orientation and perceived value explains $43.6 \%$ of the variance in satisfaction $(p<.0005)$. This finding is consistent with the theoretical assumptions from the market orientation literature which state that a firm that is market oriented and creates superior customer value enjoys increased market performance. Second, customer value offers the best predictor of customer satisfaction, with an estimated beta weight coefficient of $0.66(p<.0005)$, after controlling for the variance explained by market orientation. Therefore, preliminary support for Hypothesis 3 is found but has to be confirmed with mediation analysis. In comparison, the estimated beta weight coefficient for market orientation is only 0.04 and is not significant $(p>.72)$. This result suggests that market orientation has no direct effect on customer satisfaction (i.e. market performance).

Table 1 - Multiple regression analyses results

\begin{tabular}{|l|c|c|}
\hline \multicolumn{1}{|c|}{ Dependent variable } & $\mathrm{c}$ Customer satisfaction \\
\hline Independent variables & .038 & $\mathrm{t}$-value \\
\hline Market orientation & .666 & $.360^{*}$ \\
\hline Customer value & .457 & $6.342^{* *}$ \\
\hline R-square & .436 & \\
\hline Adjusted R-square & $21.895^{* * *}$ & \\
\hline F-model & & \\
\hline
\end{tabular}

*p > .720; ** Sig $=.000(\mathrm{p}<.0005) ; * * * \mathrm{p}<.0005$

We hypothesize an indirect effect, that is the relationship between market orientation and customer satisfaction is transmitted through customer value. As per Zhao, Lynch, and Chen (2010), mediation is deemed as 
demonstrated if the product $a b$ is non-zero. A bootstrapping is performed with the SPSS script for the indirect procedure (Preacher and Hayes, 2008): 5,000 samples are requested; and a bias-corrected and accelerated confidence interval (CI) for $a b$ is constructed.

Market orientation is predictive of perceived value $(\mathrm{a}=.16, \mathrm{p} .<.05)$; thus Hypothesis 1 is supported. Controlling for market orientation, perceived value is predictive of customer satisfaction $(b=.69, p<.001)$; thus Hypothesis 3 is supported. The upper and lower limits of the CI being .23 and .01, respectively (point estimate of $a b$ $=.11, \mathrm{p}<.05)$; thus the null of Hypothesis $2(a b=0)$ is rejected, i.e. Hypothesis 2 is supported. It may be noted that though the Sobel (1982) test is inappropriate for samples as small as the one here (Warner, 2010), it is significant too $(\mathrm{Z}=1.9481, \mathrm{p}<.001)$. Further, $\mathrm{c}^{\prime}$ being non-significant $(\mathrm{p}=.97)$, perceived value fully mediates the effect of market orientation on customer satisfaction. $\mathrm{R}^{2}(.45)$ and adjusted $\mathrm{R}^{2}(.43)$ show that the model including market orientation and perceived value explains about $2 / 5$ of the variance in customer satisfaction.

\section{DISCUSSION}

This research investigates a causal chain, market orientation $\rightarrow$ customer value $\rightarrow$ market performance. This sequence stems from the conceptualization of market orientation proposed by Narver and Slater (1990). We thus predicted that market orientation had a direct effect on perceived value, which in turn influenced the performance measured by satisfaction. Insofar as we seek to evaluate the effectiveness of market orientation using the customer's perspective, we argued that there would be a direct effect of customer value on customer satisfaction (i.e. market performance).

Our results establish that market orientation has no direct effect on satisfaction. Instead, market orientation influences customer perceived value and, though the strength of this relationship is weak, it remains statistically significant. The existence of a strong relationship between perceived value and satisfaction also emerges. The mediating role of customer value is demonstrated. These results support the theory regarding the relationships among market orientation, perceived value, and (market) performance, as proposed by Narver and Slater (1990) in their definition of market orientation and thus represent a strong contribution of this study to the literature.

The relationship between perceived value and satisfaction is strong, in line with Bagozzi's (1992) proposed causal link from cognitive to emotive. Customers' perceived value of the products offered by a corporate brand positively influences their satisfaction with those products, conforming to Fornell et al.'s (1996) results. We have adopted a relational perspective on satisfaction, as opposed to a transactional perspective, according to which overall satisfaction is a fundamental indicator of past, present, and future performance (Anderson, Fornell, and Lehmann, 1994). Thus, perceived value impacts market performance, subjectively measured through satisfaction. Practically, this finding highlights the importance of perceived value as a strategic objective of a company (Cronin, Brady, \& Hult, 2000). Its influence on market performance being revealed, perceived value can be considered "the firm's customer-based competitive advantage" (Woodruff, 1997).

In our effort to develop and analyze the construct of total market orientation (Narver et al., 2000, 2004), we also argue that total market orientation is a construct that comprises a proactive and a reactive dimension and that the two forms are empirically differentiable. To understand the value of the proactive market orientation and its contribution to the conceptual development of market orientation, from its beginnings as a single reactive component, we predicted the existence of this second-order concept of total market orientation. Our results confirm its existence and its two dimensions. In terms of understanding what it means to be market oriented, the proactive dimension is critical, in that it "rehabilitates the entrepreneurial content" of market orientation, especially in the context of new product development (Atuahene-Gima, Slater, \& Olson, 2005). However, the initial content of the two dimensions is not necessarily conserved, perhaps because the original scale was built and tested in the context of B2B relationships. Nevertheless, its transposition to the context of B2C relationships shows that it can adapt relatively well. Thus, two forms of market orientation are empirically distinct, and a business may simultaneously commit to both forms. It appears that the two forms coexist within the firms in our sample, though to differing extents. In this way, it seems that the two dimensions compensate for and complement each other. 
A major benefit of implementing a multi-perspective (i.e. dual in this study) approach to assess the effectiveness of market orientation is that it also strengthens the foundations of market orientation. The creation of superior value (for the customer) is the central objective of market orientation (see Narver and Slater, 1990), so any translation in terms of benefits from the adoption of a market orientation should be recognized and described by the company's customers in value terms.

\section{CONCLUSION AND IMPLICATIONS FOR MANAGERS}

This research has several important managerial implications. First, the results call for giving more perspective to the market orientation concept: Operationalization challenges remain. Formally, the issues lie in the gap between normative and behavioral dimensions, or those observed in an organizational culture. Reducing the gap between stated, anticipated, and effective market orientation, as it is practiced on a day-to-day basis, might have a critical influence on performance. This could condition a company's ability to build a competitive advantage, based on its organizational culture.

Second, the implementation of market orientation must comprise an evaluation of the effectiveness of market orientation. Without such evaluations, and in the absence of definitive results about the role of perceived value, perhaps managers have become alienated from market orientation concepts, as manifested in the emerging interests in alternative concepts such as an entrepreneurship orientation or innovation orientation.

Third, we have not explored the relationships between the resources available to the business and organizational processes that transform these resources into an offering that has value for the customer and ultimately leads to superior firm performance. We have assumed that market orientation catalyzes this sequence through one of its components, namely, cross-functional coordination. In this context, Baker and Sinkula (2005) consider the coordination between a strong market orientation and the resources and capabilities that contribute to improving the effectiveness of the marketing function prerequisites for increasing company performance. In a broader view, the fit between firm's marketing organizational architecture and four generic business strategies (i.e. Prospectors, Analyzers, Low-cost Defenders, and differentiated Defenders) might play an important role in generating superior business performance (see Slater, Hult, \& Olson, 2010). In terms of business practice, this key point deserves special attention.

Fourth, once questionnaires being completed, we asked several managers interviewed about their level of market orientation (The term did not appear in the questionnaire), they said "Obviously we are market-oriented!" Thus, it could be that managers treat the market orientation of their business as a matter of common sense. However, this spontaneous response may conceal different perceptions about its content. Just as a company could be entrepreneurship oriented, innovation oriented, and so forth, as most firms from our sample claim one way or another if it refers to their product or corporate communications. Realistically, we can speculate that these different orientations, if they find a conceptual content in academic research, may become entangled or overlap across different strata in a company, with managers applying them indiscriminately.

Finally, as any market situation is mutable, the relevance of concepts must also be assessed in terms of changing market conditions (increase/decrease in demand, competitive pressure, etc.) that will in all likelihood affect a firm's managerial practices. Thus, managerial relevance (see Jaworski, 2011) may be a key moderator of firm's market orientation level.

\section{Limitations and future directions}

This research suffers from several limitations. In particular, the results indicate a low impact of market orientation on perceived value, likely because value is a dynamic concept, whereas we measure it at a single point in time. Sliwotzky (1996) notes the competitive vulnerability that results from the assumption that value for the customer is a stable entity, because it allows value propositions to become less effective over time, as customers move to alternative conceptualizations of value. 
Several studies suggest that customer benefits cannot be designed exclusively in rational, economic terms (Bloom \& Reve, 1990). Accordingly, value perceptions and the explanatory factors for customer satisfaction in dynamic markets are likely to be unstable (Spreng, MacKenzie, \& Olshavsky, 1996). We cannot assume that value is the same for all customers or for all companies, because such an assumption would challenge the validity of market segmentation and the existence of strategic choices that affect the construction of a competitive advantage. In this regard, Matsuno and Mentzer (2000) show that the strategy type adopted by the firm moderates the strength of the relationship between market orientation and performance. In these conditions, we encourage future studies to use longitudinal data to study the relationship between market orientation and perceived value.

We develop and test our hypotheses with a sample of corporate brands and companies. Even with its small size, our sample of companies aims to be representative of companies selling products in consumer goods sectors. However, the vast majority of companies enjoyed strong reputations, so their managers might have been tempted to "overrate" their business practices. This tendency could explain the low dispersion among market orientation scores. It would be interesting to replicate this study with companies that are not corporate brands, to identify any differences in terms of market orientation. As the study took place in the context of consumer goods, few mediating variables might be integrated (through which the influence of market orientation on customer value passes) thus opening promising avenues for future research.

We use a measure of perceived value that, in terms of customers' perceptions, does not completely capture the extrinsic factors. The formulation of statements relating to the measurement of perceived value leads to a strong focus on quality and price, and the exclusion of other factors. One potential avenue for research would be to use a measure of perceived value that decomposes quality and price into their components (Johnson, Herrmann \& Gustafson, 2000). In addition, we use measures that are not formally relative, which means we do not account for the competition, which may limit the explanatory power of perceived value in terms of consumer behavior. A possible research path would be to use a measurement instrument that takes competitive offerings into account. In the area of services, Rust, Zeithaml, and Lemon (2000) provide a possible route for doing so.

The size of our sample (146 respondents, 55 companies) is relatively small, such that we could not conduct a confirmatory factor analysis of the total market orientation scale. The methodology we adopted to validate the total market orientation scale means it has yet to be confirmed, though this new content added to the market orientation concept opens several promising avenues for research. Other researchers should go a step further by approaching, for example, the resource-based view, management, and marketing. In these research fields, the concept of market orientation has been tackled from different perspectives, aided by different approaches (see Becker \& Homburg, 1999). This appeal of integration is clear in research into market-oriented resources, which aims to categorize market orientation as an intellectual, market-oriented resource (see Srivastava, Shervani, \& Fahey, 1998; Srivastava, Fahey, \& Christensen, 2001). Both theoretical and empirical revelations may help solve the problem of evaluating the effectiveness of market orientation from the customer's point of view. The adoption of a holistic perspective would allow for fragmented domains to be grouped together within an integrated framework that is based on common issues. Finally, it seems vital to respect the nature of market orientation and other related concepts within a theoretical framework that expands to enrich, rather than distort, the concept. This goal is especially pertinent in situations with different aggregation levels.

\section{NOTES}

In this research, the terms reactive (Narver et al., 2000) and responsive (Narver et al. 2004) [market orientation] are used interchangeably.

\section{AUTHOR INFORMATION}

Laurent Tournois, PhD, is DBA Program Director and Marketing Professor, at Grenoble Ecole de Management, France. During his PhD, he worked with Pr. Michel Montebello (IAE, Aix-en-Provence) on Customer Value Creation Strategies. His research interests are in the field of creating customer value through the management of market-based resources and proactive cannibalization processes mainly on mature markets. He previously has served as European Brand Manager at L'Oréal. He recently published a paper "Mass market leadership and 
shampoo wars: the L'Oréal Strategy » in the Journal of Business Strategy. Laurent Tournois, DBA Program Director and Marketing Professor, Grenoble Ecole de Management, 12, rue Pierre Sémard, BP 127, 38003 Grenoble Cedex 01, France. Phone number: + 334767064 87. E-mail: laurent.tournois@ grenoble-em.com

\section{REFERENCES}

1. American Customer Satisfaction Index (2001). Methodology report. American Society for Quality, Claes Fornell International, University of Michigan Business School.

2. Anderson, E.W., Fornell, C., \& D.R. Lehmann (1994). Customer satisfaction, market share, and profitability: Findings from Sweden, Journal of Marketing, 58(3), 53-66.

3. Arbuckle, J.L., \& Wothke, W. (1999). Amos users' guide; version 4.0. Chicago: Small Waters Corporation.

4. Arshad, R., Siti Mariam, M., \& Rohana, O. (2012). Market orientation, firm performance and the mediating effect of corporate social responsibility. Journal of Applied Business Research, 28(5), 851-860.

5. Atuahene-Gima, K., Slater, S.F., \& Olson, E.M. (2005). The contingent value of responsive and proactive market orientations for new product program performance. The Journal of Product Innovation Management, 22(6), 464-482.

6. Audia, P.G., Locke, E.A., \& Smith, K.G. (2000). The paradox of success: An archival laboratory study of strategic persistence following radical environment change. Academy of Management Journal, 43(5), 837853.

7. Bagozzi, R.P. (1992). The self-regulations of attitudes, intentions, and behavior. Social Psychology Quarterly, 55(2), 178-204.

8. Baker, W.E., \& Sinkula, J.M. (2005). Market orientation and the new product paradox. Journal of Product Innovation Management, 22(6), 483-502.

9. Balmer, J.M.T. (1999). Corporate identity: What of it, why the confusion, and what's next?. Corporate Reputation Review, 1(2), 183-188.

10. Becker, J., \& Homburg, C. (1999). Market-oriented management: A systems-based perspective. Journal of Market-Focused Management, 4(1), 17-41.

11. Blocker, C.P., Flint, D.J., Myers, M.B., \& Slater, S.F. (2011). Proactive customer orientation and its role for creating customer value in global markets. Academy of Marketing Science, Journal, 39, 216-233.

12. Bloom, P.N., \& Reve, T. (1990). Transmitting signals to consumers for competitive advantage. Business Horizons, 33(4), 55-66.

13. Bodlaj, M. (2010). The impact of a responsive and proactive market orientation on innovation and business performance. Economic Business Review, 12(4), 241-261.

14. Bolton, R.N., \& Drew, J.H. (1992). Mitigating the effect of service encounters. Marketing Letters, 3(1), 5770.

15. Boulding, W., Lee, E., \& Staelin, R. (1994). Mastering the mix: Do advertising, promotion, and sales force activities lead to differentiation?. Journal of Marketing Research, 31(2), 159-172.

16. Bracken, D.W, Timmreck, C.W, Fleenor, J.W, \& Summers, L. (2001). 360 feedback from another angle. Human Resource Management, 40(1), 3-20.

17. Camarero, C., \& Garrido, M.J. (2008). The role of technological and organizational innovation in the relation between market orientation and performance in cultural organizations. European Journal of Innovation Management, 11(3), 413-434.

18. Carbonell, P., \& Rodriguez Escudero, A. (2010). The effect of market orientation on innovation speed and new product performance. Journal of Business \& Industrial Marketing, 25(7), 501-513.

19. Chakravarthy, B. (1986). Measuring strategic performance. Strategic Management Journal, 7(5), 437-458.

20. Cohen, J. (1988). Statistical power analysis for the behavioral sciences. Hillsdale, NJ: Laurence Erlbaum Associates.

21. Cohen, J., \& Cohen, P. (1983). Applied multiple regression/correlation analysis for the behavioral sciences. Hillsdale, NJ: Lawrence Erlbaum Associates Publishers.

22. Cronin, J., Brady, M.K., \& Hult, G.T.M. (2000). Assessing the effects of quality, value and customer satisfaction on consumer behavioral intentions in service environments. Journal of Retailing, 76(2), 193218.

23. Day, G.S. (1999). Creating a market-driven organization. Sloan Management Review, 41(1), 11-22. 
24. Day, G.S., \& Wensley, R. (1988). Assessing advantage: A framework for diagnosing competitive superiority. Journal of Marketing, 52(2), 1-20.

25. Deshpandé, R., \& Farley, J.U. (1998). Measuring market orientation: Generalization and synthesis. Journal of Market-Focused Management, 2(3), 213-232.

26. Deshpandé, R., Farley, J.U., \& Webster, F.E. (1993). Corporate culture, customer orientation and innovativeness in Japanese firms: A quadrad analysis, Journal of Marketing, 57(1), 23-37.

27. Deshpandé, R., \& Webster, F.E. (1989). Organizational culture and marketing: Defining the research agenda. Journal of Marketing, 53(1), 3-15.

28. Flint, D.J., \& Woodruff, R.B. (2001). The indicators of changes in customers' desired value: Results from theory building study. Industrial Marketing Management, 30(4), 321-337.

29. Fornell, C. (1992). National Customer Satisfaction Barometer: The Swedish experience. Journal of Marketing, 56(1), 6-21.

30. Fornell, C., \& Johnson, M.D. (1993). Differentiation as a basis for explaining customer satisfaction across industries. Journal of Economic Psychology, 14(4), 681-696.

31. Fornell, C., Johnson, M.D., Anderson, E.W., Cha, J., \& Bryant, B.E. (1996). The American Customer Satisfaction Index: Nature, purpose, and findings. Journal of Marketing, 60(4), 7-18.

32. Gale, B.T. (1994). Managing customer value: Creating quality and service that customers can see. New York: The Free Press.

33. Gerbing, D.W., \& Anderson, J.C. (1988). An updated paradigm for scale development incorporating unidimensionality and its assessment. Journal of Marketing Research, 25(2), 186-192.

34. Green, D.H., Barclay, D.W., \& Ryans, A.B. (1995). Entry strategy and long-term performance: Conceptualization and empirical examination. Journal of Marketing, 59(4), 1-16.

35. Grisaffe, D.B., \& Kumar, A. (1998). Antecedents and consequences of customer value: Testing an expanded framework. Working Paper (98-107), Cambridge, MA: Marketing Science Institute, 1-42.

36. Hamel, G., \& Prahalad, C.K. (1994). Competing for the future. Harvard Business School Press.

37. Holbrook, M. (1996). Customer value - A framework for analysis and research. In K.P. Corfman and J.G. Lynch, Jr. (Eds) Advances in Consumer Research (23). Provo, UT: Association for Consumer Research, 138-142.

38. Holbrook, M., \& Corfman, K.P. (1985). Quality and value in the consumption experience: Phaedrus rides again. In J. Jacoby and J. Olson (Eds.) Perceived Quality: How consumers view stores and merchandise. Lexington, MA: Lexington Books, 31-57.

39. Ittner, C.D., \& Larcker, D.F. (1998). Are nonfinancial measures leading indicators of financial performance ? An analysis of customer satisfaction. Journal of Accounting Research, suppl. Studies on Enhancing the Financial Reporting Model. 36(3), 1-35.

40. Jaworski, B.J. (2011). On managerial relevance. Journal of Marketing, 75(4), 211-224.

41. Jaworski, B.J., \& Kohli, A.R. (1996). Market orientation: Review, refinement, and roadmap. Journal of Market-Focused Management, 1(2), 119-135/136.

42. Jiménez-Zarco, A.I., Torrent-Sellens, J., \& Martinez-Ruiz, M.P. (2012). Proactive orientation effects on product innovation activities: Empirical evidence. Innovation: Management, policy \& practice, 14(1), 90106.

43. Johnson, M.D., \& Fornell, C. (1991). A framework for comparing customer satisfaction across individuals and product categories. Journal of Economic Psychology, 12(2), 267-286.

44. Johnson, M.D., Herrmann, A., \& Gustafson, A. (2000). Customer satisfaction over industries, countries and time. Working Paper (00-025), Ann Arbor, MI: University of Michigan Business School, 1-39.

45. Jöreskog, K.G., \& Sörbom, D. (1989). Lisrel 7: A guide to the Program and Applications. (2 ${ }^{\text {nd }}$ ed.). Chicago, IL: SPSS.

46. Kohli, A.K., \& Jaworski, B.J. (1990). Market orientation: the construct, research propositions, and managerial implications. Journal of Marketing, 54(2), 1-18.

47. Langerak, F. (2001). The relationship between customer and supplier perceptions of the manufacturer's market orientation and its business performance. International Journal of Market Research, 43(1), 43-62.

48. Matear, S., Osborne, P., Garrett, T., \& Gray, B.J. (2002). How does market orientation contribute to service firm performance?. European Journal of Marketing, 36(9), 1058-1075.

49. Matsuno, K., \& Mentzer, J.T. (2000). The effects of strategy type on the market orientation-performance relationship. Journal of Marketing, 64(4), 1-16. 
50. McNaughton, R.B., Osborne, P., \& Imrie, B.C. (2002). Market-oriented value creation in service firms, European Journal of Marketing, 36(9/10), 990-1002.

51. Narver, J.C., \& Slater, S.F. (1990). The effect of a market orientation on business profitability. Journal of Marketing, 54(4), 20-35.

52. Narver, J.C., Slater, S.F., \& MacLachlan, D.L. (2000). Total market orientation, business performance, and innovation. Working Paper (00-116), Cambridge, MA: Marketing Science Institute, 1-34.

53. Narver, J.C., Slater, S.F., \& MacLachlan, D.L. (2004). Responsive and proactive market orientation and new-product success. The Journal of Product Innovation Management, 21(5), 334-347.

54. Netemeyer, R. G., \& Maxham, J. G. (2007). Employee versus supervisor ratings of performance in the retail customer service sector: Differences in predictive validity for customer outcomes. Journal of Retailing, 83(1), 131-146.

55. Nunnally, J.C. (1978). Psychometric theory. (2 ${ }^{\text {nd }}$ ed.). New York: McGraw-Hill.

56. Phillips, L.W. (1981). Assessing measurement error in key informant report: A methodological note on organizational analysis in marketing. Journal of Marketing Research, 18, 395-415.

57. Piercy, N.F., \& Morgan, N.A. (1997). The impact of lean thinking and the lean enterprise on marketing: Threat or synergy. Journal of Marketing Management, 13(7), 679-694.

58. Porter, M.E. (1985). Competitive advantage: creating and sustaining superior performance. New York: The Free Press.

59. Preacher, K.J., \& Hayes, A.F. (2008). Asymptotic and resampling strategies for assessing and comparing indirect effects in multiple mediator models. Behavior Research Methods, 40(3), 879-891.

60. Reinartz, W., Krafft, M., \& Hoyer, W.D. (2004). The Customer Relationship Management process: Its measurement and impact on performance. Journal of Marketing Research, 41(3), 293-305.

61. Rong, R., \& Wilkinson, I.F. (2011). What do managers' survey responses mean and what affects them? The case of market orientation and firm performance. Australasian Marketing Journal, 19(3), 137-147.

62. Rossiter, J.R. (2012). Further comment on "market orientation". Australasian Marketing Journal, 20(1), 108-112.

63. Roussel, P., Durrieu, F., Campoy, E., \& El Akremy, A. (2002). Méthodes d'équations structurelles: Recherche et applications en gestion. In Yves Simon (Ed) Recherche en Gestion. Paris: Economica.

64. Rust, R.T., Zeithaml, V.A., \& Lemon, K.N. (2000). Driving customer equity: How customer lifetime value is reshaping corporate strategy. New York: The Free Press.

65. Siguaw, J.A., Simpson, P.M., \& Baker, T.L. (1998). Effects of supplier market orientation on distributor market orientation and the channel relationship: The distributor perspective. Journal of Marketing, 62(3), 99-111.

66. Slater, S.F., and Narver, J.C. (1998). Customer-led and market-oriented: Let's not confuse the two. Strategic Management Journal, 19(10), 1001-1006.

67. Slywotzky, A.J. (1996). Value migration: How to think several moves ahead of the competition. Boston: Harvard Business School Press.

68. Slater, S.F., Hult, G.T.M., \& Olson, E.M. (2010). Factors influencing the relative importance of marketing strategy creativity and marketing strategy implementation effectiveness. Industrial Marketing Management, 39(4), 551-559.

69. Sobel, M.E. (1982). Asymptotic confidence intervals for indirect effects in structural equation models. In S. Leinhardt (Ed.), Sociological Methodology 1982 (pp. 290-312). Washington DC: American Sociological Association.

70. Spreng, R.A., MacKenzie, S.B., \& Olshavsky, R.W. (1996). A reexamination of the determinants of consumer satisfaction. Journal of Marketing, 60(3), 15-32.

71. Srivastava, R.K., Fahey, L., \& Christensen, H.K. (2001). The resource-based view and marketing: The role of market-based assets in gaining competitive advantage. Journal of Management, 27(6), 777-802.

72. Srivastava, R.K., Shervani, T.A., \& Fahey, L. (1998). Market-based assets and shareholder value: A framework for analysis. Journal of Marketing, 62(1), 2-18.

73. Tabachnick, B.G., \& Fidell, L.S. (1996). Using multivariate statistics. (3 ${ }^{\text {rd }}$ ed.). New York: Harper Collins.

74. Terawatanavong, C., Whitwell, G.J., Widing, R.E., \& O’Cass, A. (2011). Technological turbulence, supplier market orientation, and buyer satisfaction. Journal of Business Research, 64, 911-918. 
75. The Boston Consulting Group (2012). Rethinking the marketing organization. BCG Perspectives, July, accessed on November $30^{\text {th }} 2012$ at https://www.bcgperspectives.com/content/articles/consumer_products_organization_design_rethinking the _marketing_organization/

76. Tornow, W.W. (1993). Perceptions or reality: Is multi-perspective measurement a means or an end?. Human Resource Management, 32(2-3), 221-229.

77. Uncles, M.D. (2011). Researching market orientation and business performance. Australasian Marketing Journal, 19(3), 161-164.

78. Urde, M., Baumgarth, C., \& Merrilees, B. (2011). Brand orientation and market orientation — From alternatives to synergy. Journal of Business Research, doi:10.1016/j.jbusres.2011.07.018

79. Varadarajan, P.R., \& Jayachandran, S. (1999). Marketing strategy: An assessment of the state of the field and outlook. Academy of Marketing Science, Journal, 27(2), 120-143.

80. Voola, R., \& O'Cass, A. (2010). Implementing competitive strategies: The role of responsive and proactive market orientation. European Journal of Marketing, 44(1/2), 245-266.

81. Voola, R., Casimir, G., Carlson, J., \& Agnihotri, M.A. (2012). The effects of market orientation, technological opportunism, and e-business adoption on performance: A moderated mediation analysis. Australasian Marketing Journal, 20(2), 136-146.

82. Voss, G.B., \& Voss, G.Z. (2000). Strategic orientation and firm performance in an artistic environment. Journal of Marketing, 64(1), 67-83.

83. Warner, R.M (2012). Applied Statistics: From Bivariate Through Multivariate Techniques. (2 ${ }^{\text {nd }}$ ed.). Sage Publications.

84. Webb, D., Webster, C., \& Krepapa, A. (2000). An exploration of the meaning and outcomes of a customerdefined market orientation. Journal of Business Research, 48(2), 101-112.

85. Weinstein, R.B., \& Pohlman, R.A. (1998). Customer value: A new paradigm for marketing management. Advances in Business Studies, 6(10), 89-97.

86. Woodruff, R.B. (1997). Customer value: The next source for competitive advantage. Academy of Marketing Science, Journal, 25(2), 139-153.

87. Woodruff, R.B., Schumann, D.W., \& Gardial, S.F. (1993). Understanding value and satisfaction from the customer's point of view. Survey of Business, 29(1), 33-40.

88. Zhang, J., \& Duan, Y. (2010). The impact of different types of market orientation on product innovation performance. Management Decision, 48(6), 849-867.

89. Zhao, X., John, G. L., Jr, \& Chen, Q. (2010). Reconsidering Baron and Kenny: Myths and truths about mediation analysis. Journal of Consumer Research, 37(2), 197-206.

90. Zhou, K.Z., Brown, J.R., \& Dev, C.S. (2009). Market orientation, competitive advantage, and performance: A demand-based perspective. Journal of Business Research, 62(11), 1063-1070. 


\section{APPENDIX: Measurement variables}

Total market orientation - Proactive dimension

1 . We continuously try to discover additional needs of our customers of which they are unaware.

2. We incorporate solutions to unarticulated customer needs in our new products and services.

3 . We brainstorm on how customers use our products and services.

4. We innovate even at the risk of making our own products obsolete.

5. We search for opportunities in the areas where customers have a difficult time expressing their needs.

6 . We work closely with lead users who try to recognize customer needs months or even years before the majority of the market may recognize them.

7. We extrapolate key trends to gain insight into what users in a current market will need in the future.

Total market orientation - Reactive/Responsive dimension

8. We constantly monitor our level of commitment and orientation to serving customer needs.

9. We freely communicate information about our successful and unsuccessful customer experiences

10. Our strategy for competitive advantage is based on our understanding of customers' needs.

11 . We measure customer satisfaction systematically and frequently

12. We are more customer-focused than our competitors.

13. I believe this business exists primarily to serve customers.

14. Data on customer satisfaction are disseminated at all levels in this business unit on a regular basis.

Customer value

1. Rating of quality given price

2. Rating of price given quality

Customer satisfaction

1. Overall satisfaction

2. Expectancy disconfirmation (performance that falls short of or exceeds expectations

3. Performance versus the customer's ideal product in the category 


\section{$\underline{\text { NOTES }}$}

